\title{
Reciprocal Differences in Sugary $\times$ Sugary Enhancer Sweet Corn Hybrids
}

\author{
Bernardo Ordás ${ }^{1}$, Rosa A. Malvar, Amando Ordás, and Pedro Revilla \\ Consejo Superior de Investigaciones Cientificas, Plant Breeding, Carballeira 8, Salcedo, Pontevedra, \\ Galicia 36143, Spain
}

\begin{abstract}
AdDITIONAL INDEX wORDS. Zea mays, genetic background, endosperm, emergence, early vigor
ABSTRACT. Reciprocal effects in sugary $\times$ sugary enhancer hybrids of sweet corn (Zea mays L.) have been only reported for sugar content and in a very limited number of hybrids and have not been determined for agronomic traits. By evaluating 34 sugary $\times$ sugary enhancer hybrids with reciprocals in three environments, the main objectives of this work were, for agronomic and quality traits, to determine the presence or absence of reciprocal differences in the sugary $\times$ sugary enhancer hybrids, to study the interest of using sugary inbreds as seed parents of the sugary $\times$ sugary enhancer hybrids, and to determine if reciprocal differences are interacting with different genetic backgrounds and different environments. For agronomic traits as emergence, early vigor, and silking date, significant $(P \leq 0.05)$ reciprocal differences were found in many of the sugary $\times$ sugary enhancer hybrids, but for quality traits, significant $(P \leq 0.05)$ reciprocal differences were only found in a few hybrids. The sugary lines as seed parents of the crosses tended to have on average a favorable effect on agronomic traits, but this was only considerable in some environmental conditions. The difference between the sugary and sugary enhancer lines as seed parent of the crosses was strongly influenced by the genetic background.
\end{abstract}

Sugary and sugary enhancer hybrids are two of the most common types of sweet corn cultivated in temperate areas, whereas sugary $\times$ sugary enhancer hybrids, produced by crossing a sugary line with a sugary enhancer line, are also relatively common (Marshall and Tracy, 2003). The three types of hybrids are homozygous for the sugaryl (sul) mutant allele; besides, as far as the sugary enhancer gene is concerned, the sugary hybrids are homozygous for the wild allele $(\mathrm{Sel})$, the sugary enhancer hybrids are homozygous for the sugary enhancerl (se1) mutant allele, and the sugary $\times$ sugary enhancer hybrids are heterozygous having both the wild and the sugary enhancer 1 allele (Marshall and Tracy, 2003; Schultz and Juvik, 2004). The sugary enhancer hybrids (selsel genotype) have a higher quality for human consumption than the sugary hybrids ( $\mathrm{Se} 1 \mathrm{Sel}$ genotype) but reduced emergence and poor early vigor (Douglass et al., 1993; Evensen and Boyer, 1986). As a result of consumer demand, the production of sugary enhancer hybrids has increased at the expense of the sugary hybrids (Marshall and Tracy, 2003), but the expansion of sugary enhancer hybrids to areas with short-season or cool environments such as Atlantic Europe, Canada, some areas of the U.S. Corn Belt, and so on is limited by their poor stand establishment. The sugary $\times$ sugary enhancer crosses are an appropriate alternative for those areas because they have an acceptable stand establishment, better than sugary enhancer hybrids, and a table quality that improves that of sugary hybrids (Ordas et al., 2008).

Differences between reciprocal $F_{1}$ crosses for horticulturally important characters can influence decisions at many steps in a breeding program (Hansen and Baggett, 1977). Although reciprocal cross differences have been reported by several

Received for publication 14 July 2008. Accepted for publication 23 Aug. 2008. Research supported by the National Plan for Research and Development of Spain (Project Cod. AGL2001-3946) and Excma. Diputación Provincial de Pontevedra, Spain.

${ }^{1}$ Corresponding author. E-mail: bernardo@mbg.cesga.es. authors for field corn (Mann et al., 1981; Melchinger et al., 1985; Revilla et al., 1999), limited results have been published in the case of sweet corn (Hansen and Baggett, 1977; Tracy, 1990). The maize kernel includes the pericarp, a maternal tissue, and the embryo, which are diploid, and the endosperm, which is triploid, having two doses of each gene coming from the female and one from the male (Darrah et al., 2003). Regarding the sugary $\times$ sugary enhancer hybrids, when the sugary enhancer inbred is the seed parent, the endosperm has two doses of each gene coming from the sugary enhancer inbred and one from the sugary inbred and, therefore, it has two sel alleles and one $\mathrm{Se} 1$ allele, whereas the pericarp is equal to that of the sugary enhancer inbred. On the contrary, when the sugary inbred is the seed parent, the endosperm has two doses of each gene coming from the sugary inbred and one from the sugary enhancer and, therefore, it has two Sel alleles and one sel allele, whereas the pericarp is equal to that of the sugary inbred. Proksch and Juvik (1988) found for a sugary $\times$ sugary enhancer hybrid (IL451b $\times$ IL677a) that the total sugar content was higher when the sugary enhancer line was the seed parent of the cross. Kurilich et al. (1996), using two isogenic lines, found that the sugar content was higher with one sel allele than with two se 1 alleles for IL451b; however, the sugar content was similar with one and two se1 alleles for IL678a. The contradictory results and the very few number of hybrids evaluated leaves the question of the importance of the reciprocal effects for the kernel sugar content of the sugary $\times$ sugary enhancer hybrid unresolved. Are, in general, the reciprocal effects important as they are in the two hybrids from IL451b? Alternatively, are they not important as in the hybrid from IL678a? A third possibility, given the data, is that the magnitude of the reciprocal effects depended on the particular lines involved.

Juvik et al. (2003) evaluated $214 \mathrm{~F}_{2: 3}$ families coming from a sugary $\times$ sugary enhancer hybrid $($ W6786 $\times$ IL731a) and measured emergence and seedling growth rate. The genetic backgrounds of the sugary and the sugary enhancer inbreds were mixed in all families. Regarding the sel allele, in some of 
the families, the allelic dosage for sel was constant for all plants: either none or three sel alleles, but in other families, the allelic dosage varied between plants from none to three. With this experimental design, it was not possible to estimate reciprocal effects in sugary $\times$ sugary enhancer hybrids or to compare the effect of allele dosage on emergence or other traits, particularly the difference between hybrids with one or two sel alleles (difference that is found in the reciprocal sugary $\times$ sugary enhancer hybrids). Anyway, because the study was based on only one single cross, their conclusions could not be generalized to other sweet corn germplasms.

The performance of the parental inbreds of a cross can be used to predict which line will be more adequate as the female parent when the relationships between the reciprocal differences of the hybrids and their respective parents are strong enough (Mann and Pollmer, 1981). However, data about this relationship have not been reported for sweet corn. Also, to choose the female parent of a cross, it would be interesting to know the relationships between the reciprocal effects of different traits.

Summarizing, reciprocal effects in sugary $\times$ sugary enhancer hybrids have been only reported for sugar content in the kernel and not for agronomic traits; furthermore, the effects on the sugar content are found to be contradictory in the very limited number of hybrids evaluated. By evaluating 34 sugary $\times$ sugary enhancer hybrids with reciprocals, the objectives of this work were for both agronomic and quality traits to determine the presence or absence of reciprocal differences in sugary $\times$ sugary enhancer hybrids, to study the interest of using sugary inbreds as seed parents of sugary $\times$ sugary enhancer hybrids, and to determine if reciprocal differences are interacting with different genetic backgrounds and different environments. Additional objectives were to examine the relationships between inbred lines of sweet corn and the reciprocal effects of their hybrids and the relationships between the reciprocal effects of the different traits.

\section{Materials and Methods}

Six sugary lines and seven sugary enhancer lines (Table 1) were used as the parental lines of 34 sugary $\times$ sugary enhancer hybrids with reciprocals (the hybrids are shown in Table 2). All but one of the sugary lines come from three historically important open-pollinated cultivars: Evergreen, Country Gentleman, and Golden Bantam, that have made the greatest contribution to modern sugary germplasm. The allele se1 was originally identify in IL667a (Gonzales et al., 1974) and quickly incorporated into many breeding program (Tracy, 2001). Except IL677a, no other original source for the sel allele has been reported and so probably all existing inbred lines with the sel allele derive from IL667a. Four of the sugary enhancer inbreds used in the present work are related to IL667a (Rhodes et al., 1982) and the two lines with unknown pedigree are probably related to IL677a also.

The hybrids were evaluated in a randomized complete block design with two replications during 1999 and 2000 at Pontevedra, Spain (Environments 1 and 2, respectively) and during 1999 at Pontecaldelas, Spain (Environment 3). Pontevedra (lat. $42^{\circ} 24^{\prime} \mathrm{N}$, long. $8^{\circ} 38^{\prime} \mathrm{W}$ ) is at $20 \mathrm{~m}$ and Pontecaldelas (lat. $42^{\circ} 23^{\prime} \mathrm{N}$, long. $8^{\circ} 32^{\prime} \mathrm{W}$ ) at $300 \mathrm{~m}$ above sea level with cool and wet springs and a short summer, conditions similar to those found in many areas of western Europe (Table 2). The soil is acid sandy loam and the agronomic handling was done according to the local practices. Each single-row experimental plot consisted of 20 hills with two kernels per hill. The rows were spaced $0.8 \mathrm{~m}$ apart and hills $0.21 \mathrm{~m}$ apart. All hills were thinned to one plant to achieve a final plant density of $\approx 60,000$ plants/ha. All the seed for the experiment had been obtained the previous year in the same location.

Two traits related to stand establishment, namely emergence and early vigor, were measured on each plot. Emergence was measured as the percentage of emerged plants. Early vigor was measured on a subjective scale from 1 (very poor) to 9 (very good) at the five-leaf stage. Silking date was computed as the number of days from planting to $50 \%$ of plants showing silks. Plant height, ear length, ear diameter, row number, kernel depth, and kernel width were measured on five plants taken from competitive adult plants in each plot. Yield was measured in each plot and adjusted at a kernel moisture of $140 \mathrm{~g} \cdot \mathrm{kg}^{-1} \mathrm{H}_{2} \mathrm{O}$. Five trained panelists, who tested three ears per plot, determined table quality, which can be defined as the overall judgment on pericarp hardness, texture, and flavor. The soluble solid content of the same ears was measured with a hand refractometer.

A combined analysis of variance over environments was performed for each trait. For each hybrid, the difference

Table 1 . Name, pedigree, and origin of the sugary and sugary enhancer parental inbred lines of the 34 sugary $\times$ sugary enhancer hybrids of sweet corn grown in three environments.

\begin{tabular}{|c|c|c|c|}
\hline Name & Pedigree & Name & Pedigree \\
\hline \multicolumn{2}{|c|}{ Sugary inbreds } & \multicolumn{2}{|c|}{ Sugary enhancer inbreds } \\
\hline EP59z & $\mathrm{IL} 27 \mathrm{a} \times \mathrm{I} 5125$ & IL731aw & Golden Sensation $\times$ IL677a \\
\hline $\mathrm{EP}^{2} 2^{\mathrm{z}}$ & $\mathrm{I} 453 \times \mathrm{P} 51$ & ${\text { IL } 778 d^{w}}^{w}$ & IL557a $\times$ IL677a \\
\hline $\mathrm{I} 5125^{\mathrm{y}}$ & $($ IP39 $\times$ Tendermost $) \times$ IP39 & IL 779a $a^{w}$ & White dent $\times$ IL677a \\
\hline V7726 $6^{\mathrm{x}}$ & North Star $\times$ Gold Cup & $\mathrm{We}^{\mathrm{v}}$ & Closed \\
\hline
\end{tabular}

\footnotetext{
${ }^{\mathrm{z}}$ Misión Biológica de Galicia, Pontevedra, Spain.

'⿳亠口冋口十 Agricultural Experimental Station, Ames.

${ }^{x}$ Horticultural Experimental Station of Simcoe, Ontario, Canada.

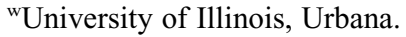

vUniversity of Wisconsin, Madison.
} 
Table 2. Monthly average temperature, mean of the minimum daily temperature, and rainfall during the maize growing cycle in Pontevedra and Pontecaldelas (Spain), the locations where the experiments were carried out.

\begin{tabular}{|c|c|c|c|c|c|c|c|c|}
\hline & \multicolumn{6}{|c|}{ Temperature $\left({ }^{\circ} \mathrm{C}\right)$} & & \\
\hline & \multicolumn{3}{|c|}{ Avg. } & \multicolumn{3}{|c|}{ Avg. daily minimum } & \multirow{2}{*}{\multicolumn{2}{|c|}{$\begin{array}{c}\text { Rainfall (mm) } \\
\text { Pontevedra }\end{array}$}} \\
\hline & \multicolumn{2}{|c|}{ Pontevedra } & \multirow{2}{*}{$\frac{\text { Pontecaldelas }^{\mathrm{z}}}{2007}$} & \multicolumn{2}{|c|}{ Pontevedra } & \multirow{2}{*}{$\frac{\text { Pontecaldelas }}{2007}$} & & \\
\hline & 1999 & 2000 & & 1999 & 2000 & & 1999 & 2000 \\
\hline May & 16 & 16 & 13 & 10 & 10 & 8 & 100 & 128 \\
\hline June & 18 & 19 & 15 & 12 & 12 & 10 & 36 & 24 \\
\hline
\end{tabular}

${ }^{\mathrm{z}}$ Temperature data from Pontecaldelas are only available since 2007.

between reciprocals was tested by a $t$ test using the SE from the combined analysis of variance. For each trait, we made the comparison "crosses with the sugary line as the parental seed" versus "crosses with the sugary enhancer as the parental seed" (for simplicity, we name this comparison sugary versus sugary enhancer). The same comparison was made for each subgroup of reciprocal hybrids with a common sugary inbred line. The components of the sum of squares for crosses resulting from these comparisons and for crosses $\times$ environment resulting from the interaction of these comparisons with environment were computed and tested by an $\mathrm{F}$ test. For each trait, Pearson's coefficient of correlation between the mean reciprocal difference of the hybrids of each inbred line (general reciprocal difference of the line) and the per se value of the inbred line was calculated to control if the well-performing parents are more adequate as the seed parent of the crosses. Finally, to study the relationship between the reciprocal effects of the different traits, Pearson's coefficients of correlation between the reciprocal effects of each pair of traits were calculated. All analyses were performed using SAS (Version 9.1; SAS Institute, Cary, NC).

\section{Results and Discussion}

Significant reciprocal differences were found in many of the hybrids for the agronomic traits emergence, early vigor, yield, and silking date (Table 3 ). The traits measured on the earlier stages of the plant development are expected to be more affected by reciprocal effects because both endosperm and pericarp play an important role by protecting the embryo and by feeding the seedling. As our results indicate, these effects can persist during all plant development, which is in accordance with Fakorede and Agbana (1983) and Ajala and Fakorede (1988) who found that early vigor is positively correlated with silking date and yield. Hansen and Baggett (1977) also reported significant reciprocal effects for a number of traits in sweet corn, but Tracy (1990) did not. It is important to stress that those experiments were carried out in one and two environments, respectively, whereas our study was carried out in three different environments and, unlike the other studies, it included not only sul lines, but also sulsel lines. For the other agronomic traits measured in this study, the reciprocal effects were not important because they were only significant in five or less of the hybrids (Table 3).

The comparison sugary versus sugary enhancer was significant for ear diameter and number of rows, but not significant for the rest of the agronomic traits (Table 4). The average difference was equal to $0.3 \mathrm{~mm}$ and 0.3 rows, respectively, the crosses with the sugaryl line as the seed parent having the higher value for both traits. There was a significant interaction between the comparison sugary versus sugary enhancer and environment for emergence and ear length. For emergence, in Environment 3, the average value of the crosses was $7 \%$ higher (significant at $P \leq 0.01$ ) when the sugary line was the seed parent, but only $2 \%$ higher in the other environments (not significant at $P \leq 0.05$ ). Also, for early vigor, the average value of the crosses was 0.25 higher (significant at $P \leq 0.1$ ) when the sugary line was the seed parent in Environment 3, but only 0.10 higher in the other environments (not significant at $P \leq 0.1$ ). For other traits such as ear length and yield, the difference between the sugary versus sugary enhancer line as the seed parent of the crosses was also significant at $P \leq 0.01$ and $P \leq 0.1$, respectively, in Environment 3. Therefore, our results suggest that for several agronomic traits, like for example emergence and early vigor, the sugary lines tend to be better than the sugary enhancer lines as the seed parent of the crosses, but the difference is only appreciable for some environmental conditions.

The reciprocal sugary $\times$ sugary enhancer hybrids differ in the endosperm ( 1 versus 2 sel alleles) and in the pericarp (none versus 2 sel alleles) genetic constitution, but not in the genotype of the embryo. Therefore, according to our results, an additional sel allele in the genetic constitution of the endosperm and a sugary enhancer pericarp do not produce a considerable effect on emergence or early vigor, except for particular environmental conditions. However, large differences were found by Ordas et al. (2008) for emergence and early vigor between sugary and sugary enhancer hybrids. The difference between the pericarps of sugary and sugary enhancer hybrids is equal to that found between the pericarps of reciprocal sugary $\times$ sugary enhancer hybrids, but the endosperms of sugary and sugary enhancer hybrids differ by three se 1 alleles, not by one like the reciprocal sugary $\times$ sugary enhancer hybrids. Furthermore, unlike reciprocal sugary $x$ sugary enhancer hybrids, the sugary and sugary enhancer hybrids differ in the genetic constitution of the embryo (none versus two sel alleles).

Although on average the hybrids with the sugary lines as the seed parent tended to have better emergence and early vigor than the hybrids with the sugary enhancer lines as the seed parent, the advantage of the sugary lines was strongly dependent on the particular inbred lines involved in the sugary $\times$ sugary enhancer crosses. Thus, for the hybrids with 
Table 3. Differences between reciprocal means ( $F_{1}$ with the sugary inbred as seed parent minus $F_{1}$ with the sugary enhancer inbred as seed parent $)$ for 12 characters of 34 sugary $\times$ sugary enhancer sweet corn hybrids grown in three environments.

\begin{tabular}{|c|c|c|c|c|c|c|c|c|c|c|c|c|}
\hline Hybrid & $\begin{array}{c}\text { Emergence } \\
(\%)\end{array}$ & $\begin{array}{l}\text { Early } \\
\text { vigor } \\
(1-9)^{z} \\
\end{array}$ & $\begin{array}{c}\text { Plant ht } \\
(\mathrm{cm})\end{array}$ & $\begin{array}{l}\text { Ear } \\
\text { length } \\
(\mathrm{cm})\end{array}$ & $\begin{array}{c}\text { Ear } \\
\text { diam. } \\
(\mathrm{mm})\end{array}$ & $\begin{array}{l}\text { Rows } \\
\text { (no.) }\end{array}$ & $\begin{array}{l}\text { Kernel } \\
\text { depth } \\
(\mathrm{mm})\end{array}$ & $\begin{array}{l}\text { Kernel } \\
\text { width } \\
(\mathrm{mm})\end{array}$ & $\begin{array}{c}\text { Yield } \\
\left(\mathrm{mg} \cdot \mathrm{ha}^{-1}\right)\end{array}$ & $\begin{array}{c}\text { Table } \\
\text { quality } \\
(1-9 \text { scale })^{z}\end{array}$ & $\begin{array}{c}\text { Soluble } \\
\text { solids } \\
(\%)\end{array}$ & $\begin{array}{c}\text { Silking } \\
\text { date (DAP) }\end{array}$ \\
\hline EP58 $\times$ IL677a & $32.5^{*}$ & 0.7 & $56.7^{*}$ & $3.2 *$ & $7.9 *$ & $6.8^{*}$ & $2.5^{*}$ & $0.43^{*}$ & $1.6^{*}$ & $1.5^{*}$ & -2.2 & 1.2 \\
\hline EP58 $\times$ IL731a & $-28.5^{*}$ & $-1.3^{*}$ & -9.6 & -0.6 & -1.7 & -0.9 & -0.8 & -0.07 & $-2.1^{*}$ & -0.4 & 0.7 & 0.7 \\
\hline EP58 $\times$ IL767b & 6.3 & $1.7^{*}$ & 13.4 & 1.0 & 0.7 & 1.1 & -0.0 & 0.03 & $1.7 *$ & -0.1 & -0.8 & $-3.3 *$ \\
\hline EP58 $\times$ IL778d & 14.2 & 0.2 & -4.6 & 1.6 & 0.8 & 0.6 & 0.2 & -0.03 & 0.8 & -0.2 & -0.2 & -1.0 \\
\hline EP58 $\times$ IL779a & $16.7^{*}$ & 0.5 & -5.4 & 0.0 & 0.4 & -0.7 & 0.5 & -0.01 & -0.1 & -0.4 & -0.3 & $2.5^{*}$ \\
\hline $\mathrm{EP} 58 \times \mathrm{We} 10 \mathrm{t}$ & $30.6^{*}$ & $1.2 *$ & -1.8 & 0.8 & 0.2 & 1.1 & -0.1 & -0.10 & $1.3 *$ & 0.5 & 0.5 & $-2.3 *$ \\
\hline EP58 × We6 & $18.8^{*}$ & $1.5^{*}$ & -1.5 & 0.3 & 0.8 & 0.6 & 0.2 & -0.16 & 0.2 & 0.0 & 1.5 & -0.2 \\
\hline EP59 $\times$ IL677a & $20.0^{*}$ & 1.0 & -8.2 & 0.4 & 1.7 & 0.1 & 0.9 & 0.02 & 0.2 & -0.1 & -1.2 & -1.8 \\
\hline EP59 $\times$ IL731a & $-18.3^{*}$ & $-2.5^{*}$ & -2.3 & -1.3 & -1.2 & -0.3 & -0.8 & 0.04 & $-1.6^{*}$ & -0.7 & 0.5 & $3.2^{*}$ \\
\hline EP59 $\times$ IL767b & -5.4 & -0.7 & $-17.3^{*}$ & 0.3 & -0.4 & 0.4 & 0.0 & -0.07 & -1.1 & -0.5 & 0.7 & -1.3 \\
\hline EP59 $\times$ IL778d & $-26.3^{*}$ & $-2.8^{*}$ & -5.8 & -0.4 & -0.7 & 0.4 & -0.3 & 0.01 & $-2.5^{*}$ & -0.5 & 0.2 & $6.5^{*}$ \\
\hline EP59 $\times$ IL779a & 1.3 & $-2.0^{*}$ & -0.9 & 0.3 & 0.4 & -0.5 & 0.4 & -0.2 & $-1.6^{*}$ & 0.8 & 1.5 & $2.3^{*}$ \\
\hline EP59 $\times$ We10t & $-26.0 *$ & $-1.8^{*}$ & -7.2 & -0.2 & -1.2 & -0.2 & -0.4 & 0.04 & $-1.3^{*}$ & 0.23 & 1.7 & $3.5^{*}$ \\
\hline EP59 × We 6 & -7.3 & 0.0 & 8.5 & 0.5 & $2.7^{*}$ & $1.4^{*}$ & $1.2 *$ & -0.05 & 0.4 & -0.2 & $-3.7^{*}$ & 0.2 \\
\hline EP60 $\times$ IL677a & $38.8^{*}$ & $1.5^{*}$ & 4.5 & 1.0 & -0.5 & 0.1 & -0.3 & -0.08 & $1.5^{*}$ & $1.4^{*}$ & -1.7 & -0.5 \\
\hline EP60 $\times$ IL731a & -4.6 & 0.3 & 8.5 & $2.0^{*}$ & 1.6 & -0.4 & $0.9 *$ & 0.04 & 0.3 & $-0.9 *$ & 0.3 & $-2.0 *$ \\
\hline $\mathrm{EP} 60 \times \mathrm{IL} 767 \mathrm{~b}$ & $15.8 *$ & $1.3^{*}$ & $15.5^{*}$ & 1.7 & 1.2 & 1.1 & 0.1 & 0.05 & $1.4^{*}$ & 0.6 & -2.3 & $-2.3 *$ \\
\hline EP60 $\times$ IL778d & 14.6 & 0.2 & -6.4 & 0.1 & -0.7 & -0.4 & -0.1 & 0.02 & -0.7 & 0.2 & -0.2 & 0.0 \\
\hline EP60 $\times$ IL779a & 8.8 & -0.2 & -1.8 & -1.6 & -0.7 & 0.33 & 0.1 & 0.02 & -0.4 & 0.3 & 3.2 & 1.0 \\
\hline $\mathrm{EP} 60 \times \mathrm{We} 10 \mathrm{t}$ & $19.0^{*}$ & 1.0 & 0.9 & 0.1 & -0.2 & -0.2 & -0.2 & -0.09 & 1.2 & 0.5 & -2.0 & -1.2 \\
\hline EP60 × We 6 & $16.7^{*}$ & 1.0 & 3.1 & -0.7 & -0.1 & 0.1 & 0.2 & 0.03 & 0.6 & 0.7 & 0.2 & -0.7 \\
\hline EP62 $\times$ IL677a & 6.7 & 0.8 & -1.2 & 0.2 & 1.1 & 0.5 & 0.4 & 0.09 & 0.8 & 0.04 & -1.3 & $-2.0^{*}$ \\
\hline EP62 $\times$ IL731a & 6.3 & $1.5^{*}$ & 3.2 & 0.0 & -0.1 & 0.5 & 0.2 & 0.08 & 0.8 & 0.3 & 0.3 & $-4.0^{*}$ \\
\hline EP62 $\times$ IL767b & 0.0 & -0.2 & -5.9 & 1.3 & 0.1 & -0.5 & -0.3 & -0.17 & -0.2 & -0.1 & -1.3 & -1.3 \\
\hline EP62 $\times$ IL778d & -14.2 & -0.8 & -5.0 & 0.5 & -0.9 & $-1.5^{*}$ & -0.6 & 0.05 & -0.7 & 0.4 & -1.0 & $2.0 *$ \\
\hline EP62 $\times$ IL779a & -1.3 & -0.3 & -3.8 & 0.4 & 0.1 & 0.5 & -0.0 & 0.16 & 0.1 & 0.01 & 1.0 & 0.33 \\
\hline EP62 × We 6 & 1.1 & $2.2^{*}$ & $16.8^{*}$ & -0.3 & 0.8 & 0.4 & 0.7 & 0.11 & 0.5 & 0.33 & 0.8 & -0.5 \\
\hline I5125 × IL677a & $27.0^{*}$ & $1.5^{*}$ & 6.6 & 0.4 & 0.8 & 0.8 & 0.8 & 0.09 & 1.1 & 0.1 & 0.0 & $-3.3^{*}$ \\
\hline I5125 × IL731a & 6.3 & 0.8 & -10.3 & -0.6 & -0.2 & 0.11 & 0.2 & -0.04 & $1.6^{*}$ & 0.7 & -1.3 & 0.2 \\
\hline I5125 × IL778d & 7.5 & 0.2 & -3.7 & -0.4 & -1.7 & -0.6 & $-1.2 *$ & $0.24 *$ & -0.0 & 0.6 & -1.0 & -0.3 \\
\hline V7726 × IL677a & $-20.3^{*}$ & 0.3 & -1.1 & -0.0 & -0.0 & -0.5 & 0.2 & 0.12 & -0.8 & -0.4 & 0.2 & $-2.2 *$ \\
\hline V7726 × IL731a & $-17.8^{*}$ & $-2.2 *$ & -1.0 & -0.8 & -0.3 & -0.3 & $-1.0 *$ & $0.29 *$ & $-2.3 *$ & -0.5 & 0.8 & $3.0 *$ \\
\hline V7726 $\times$ IL767b & -5.0 & 0.7 & -8.6 & -0.7 & 0.7 & 0.3 & 0.1 & 0.01 & 0.3 & -0.0 & -0.5 & -1.0 \\
\hline V7726 × We10t & -9.0 & -0.2 & 1.5 & 1.0 & 1.2 & 0.5 & -0.0 & 0.04 & 0.6 & -0.4 & 0.33 & 0.5 \\
\hline $\operatorname{LSD}(5 \%)$ & 15.6 & 1.1 & 13.9 & 1.8 & 2.2 & 1.1 & 0.9 & 0.21 & 1.3 & 0.9 & 3.2 & 2.0 \\
\hline CV $(\%)$ & 16.3 & 17.4 & 5.2 & 7.5 & 3.8 & 6.3 & 6.3 & 3.7 & 25.9 & 13.6 & 12.7 & 2.3 \\
\hline
\end{tabular}

${ }^{\mathrm{z}}$ Subjective scale from 1 (very poor) to 9 (very good).

*,** Significant at $P \leq 0.05$ and $P \leq 0.01$, respectively.

$\mathrm{DAP}=$ days after planting.

the sugary inbreds EP58, EP60, and I5125 as seed parents, the emergence was on average $15 \%$ higher (significant at $P \leq 0.01)$ than the emergence of the same hybrids with a sugary enhancer inbred as seed parent, but for the reciprocal hybrids with the sugary inbreds EP59 and V7726 as seed parents, the emergence was on average, $\approx 10 \%$ lower (significant at $P \leq 0.01$ ). Similarly, for early vigor, the hybrids with the sugary inbreds EP58, EP60, EP62, and I5125 as seed parents had scores 0.7 higher (significant at $P \leq 0.05)$ than the same hybrids with a sugary enhancer inbred as the seed parent, but the reciprocal hybrids with the sugary inbred EP59 as the seed parent had scores 1.2 lower (significant at $P \leq 0.05$ ).

The correlation coefficient between the performance and the general reciprocal difference of the inbreds was significant for early vigor $(r=0.72, P \leq 0.01)$, but not significant for the rest of agronomic traits. These results agree with those of Mann and Pollmer (1981 and references therein) who found significant correlations between reciprocal effects and performance of the lines only in a limited number of agronomic traits. In conclusion, prediction of whether a line should be used as the male or the female parent based in the performance of the line seems to be possible only for early vigor, but even for this trait, the coefficient of determination is not too high $(\approx 0.5)$ and so reciprocal crosses could be necessary to detect reciprocal differences.

There was a significant relationship between the reciprocal effects of different agronomic traits (Table 5). As expected, ear diameter was positively correlated with row number and kernel depth and yield was correlated to ear length. There were significant correlation coefficients between traits measured at early development stages (emergence and early vigor) and traits 
Table 4. Mean squares from the combined analyses of variance for 12 characters of 34 sugary $\times$ sugary enhancer hybrids of sweet corn with reciprocals grown in three environments. ${ }^{z}$

\begin{tabular}{|c|c|c|c|c|c|c|c|c|c|c|c|c|c|}
\hline Source & df & $\begin{array}{c}\text { Emer- } \\
\text { gence } \\
(\%)\end{array}$ & $\begin{array}{l}\text { Early } \\
\text { vigor } \\
(1-9)^{y}\end{array}$ & $\begin{array}{l}\text { Plant ht } \\
(\mathrm{cm})\end{array}$ & $\begin{array}{c}\text { Ear } \\
\text { length } \\
(\mathrm{cm})\end{array}$ & $\begin{array}{c}\text { Ear } \\
\text { diam. } \\
(\mathrm{mm})\end{array}$ & $\begin{array}{c}\text { Rows } \\
\text { (no.) }\end{array}$ & $\begin{array}{l}\text { Kernel } \\
\text { depth } \\
(\mathrm{mm})\end{array}$ & $\begin{array}{l}\text { Kernel } \\
\text { width } \\
(\mathrm{mm})\end{array}$ & $\begin{array}{c}\text { Table } \\
\text { yield } \\
\left(\mathrm{mg} \cdot \mathrm{ha}^{-1}\right)\end{array}$ & $\begin{array}{c}\text { Soluble } \\
\text { quality } \\
(1-9 \text { scale })^{y}\end{array}$ & $\begin{array}{l}\text { Silking } \\
\text { solids } \\
(\%)\end{array}$ & $\begin{array}{l}\text { Date } \\
\text { (DAP) }\end{array}$ \\
\hline Crosses $(\mathrm{C})$ & 67 & $* *$ & $* *$ & $* *$ & $* *$ & $* *$ & $* *$ & $* *$ & $* *$ & $* *$ & $* *$ & $* *$ & $* *$ \\
\hline $\mathrm{C} \times \mathrm{E}$ & 134 & $* *$ & NS & NS & $*$ & NS & NS & $*$ & $*$ & $*$ & NS & $*$ & NS \\
\hline$S e 1$ versus $\operatorname{sel}^{\mathrm{x}} \times \mathrm{E}$ & 2 & $*$ & NS & NS & $*$ & NS & NS & NS & NS & NS & NS & NS & NS \\
\hline
\end{tabular}

${ }^{\mathrm{z}}$ The mean squares for the comparison crosses with the sugary line as the parental seed versus crosses with the sugary enhancer as the parental seed (sugary versus sugary enhancer) and for the interaction of the comparison with environment (E) are also shown.

${ }^{y}$ Subjective scale from 1 (very poor) to 9 (very good).

${ }^{\mathrm{x}}$ Comparison sugary versus sugary enhancer.

Ns, **** Nonsignificant or significant at $P \leq 0.05$ and $P \leq 0.01$, respectively.

$\mathrm{DAP}=$ days after planting.

Table 5. Correlation coefficients between the reciprocal effects of each pair of traits obtained from the evaluation of 34 sugary $\times$ sugary enhancer hybrids of sweet corn with reciprocals grown in three environments.

\begin{tabular}{|c|c|c|c|c|c|c|c|c|c|c|c|}
\hline & $\begin{array}{l}\text { Early } \\
\text { vigor } \\
(1-9)^{\mathrm{z}}\end{array}$ & $\begin{array}{l}\text { Plant ht } \\
\text { (cm) }\end{array}$ & $\begin{array}{c}\text { Ear } \\
\text { length } \\
(\mathrm{cm})\end{array}$ & $\begin{array}{l}\text { Ear diam. } \\
(\mathrm{mm})\end{array}$ & $\begin{array}{c}\text { Rows } \\
\text { (no.) }\end{array}$ & $\begin{array}{l}\text { Kernel } \\
\text { depth } \\
(\mathrm{mm})\end{array}$ & $\begin{array}{l}\text { Kernel } \\
\text { width } \\
(\mathrm{mm})\end{array}$ & $\begin{array}{c}\text { Yield } \\
\left(\mathrm{mg} \cdot \mathrm{ha}^{-1}\right)\end{array}$ & $\begin{array}{c}\text { Table } \\
\text { quality } \\
(1-9 \text { scale })^{z}\end{array}$ & $\begin{array}{c}\text { Soluble } \\
\text { solids } \\
(\%)\end{array}$ & $\begin{array}{l}\text { Silking } \\
\text { date } \\
\text { (DAP) }\end{array}$ \\
\hline Emergence & $0.71 * *$ & $0.39 *$ & $0.57 * *$ & $0.37^{*}$ & $0.41^{*}$ & $0.40^{*}$ & 0.03 & $0.77 * *$ & $0.61 * *$ & -0.30 & $-0.48 * *$ \\
\hline Plant ht & & & $0.59 * *$ & $0.83 * *$ & $0.87 * *$ & $0.68^{* *}$ & $0.60^{* *}$ & $0.50 * *$ & $0.51 * *$ & $-0.37^{*}$ & -0.10 \\
\hline Ear length & & & & $0.68 * *$ & $0.61 * *$ & $0.59 * *$ & 0.13 & $0.66^{* *}$ & 0.32 & $-0.46^{* *}$ & $-0.51 * *$ \\
\hline Ear diam. & & & & & $0.87 * *$ & $0.90 * *$ & $0.44 * *$ & $0.49 * *$ & 0.29 & $-0.38^{*}$ & -0.16 \\
\hline Kernel width & & & & & & & & 0.17 & 0.17 & -0.13 & 0.02 \\
\hline Yield & & & & & & & & & $0.56^{* *}$ & $-0.54 * *$ & $-0.62 * *$ \\
\hline Table quality & & & & & & & & & & -0.25 & -0.07 \\
\hline Soluble solids & & & & & & & & & & & 0.27 \\
\hline
\end{tabular}

${ }^{\mathrm{z}}$ Subjective scale from 1 (very poor) to 9 (very good).

*,** Significant at $P \leq 0.05$ and $P \leq 0.01$, respectively.

$\mathrm{DAP}=$ days after planting.

of later stages such as silking date or yield, which is in accordance with Revilla et al. (1999) who found a significant correlation between the reciprocal effects of early vigor and silking date.

For the quality traits table quality and soluble solids, the reciprocal effects were significant in three and one of the hybrids, respectively (Table 3 ), indicating that in the sugary $\times$ sugary enhancer hybrids, the reciprocal effects are, in general, not important for quality traits. The comparison sugary versus sugary enhancer was not significant for the quality traits (Table 4) and, therefore, which kind of line, either sugary or sugary enhancer, is the seed parent of the cross is irrelevant for quality traits.

Regarding the correlations between the reciprocal effects of agronomic and quality traits, what is remarkable is the small, but significant and positive, correlation of emergence and vigor with table quality. The hybrids with the lowest stand establishment are expected to be more negatively affected by stress conditions during the early stages of the development and those negative effects could persist until the adult phase and affect the plant ability to produce a high-quality kernel. Reciprocal cross differences have been reported in the case of sweet corn only for agronomic traits (Hansen and Baggett, 1977; Tracy, 1990) and, therefore, no data are available to compare with our results. From our results, we could conclude that if a line is selected as the seed parent because the hybrid has better emergence and vigor, the table quality of the hybrid will be also better or at least will not be worse.

The main conclusions of this work are first, reciprocal differences in sugary $\times$ sugary enhancer hybrids are common for some agronomic traits such as emergence and early vigor, but not for quality traits; second, the sugary lines as seed parents of the crosses tend to have on average a favorable effect on emergence, early vigor, and other agronomic traits, but this is only appreciable in some environmental conditions; third, the difference between the sugary and sugary enhancer lines as seed parents of the crosses is strongly influenced by the genetic background.

\section{Literature Cited}

Ajala, S.O. and M.A.B. Fakorede. 1988. Inheritance of seedling vigor and its association with mature plant traits in a maize population at two levels of inbreeding. Maydica 33:121-129.

Darrah, L.L., M.D. McMullen, and M.S. Zuber. 2003. Breeding, genetics, and seed corn production, p. 35-68. In: P.J. White and L.A. Johnson (eds.). Corn: Chemistry and technology. 2nd ed. American Assn. Cereal Chemists, St. Paul, MN.

Douglass, S.K., J.A. Juvik, and W.E. Splittstoesser. 1993. Sweet corn seedling emergence and variation in kernel carbohydrate reserves. Seed Sci. Technol. 21:433-445. 
Evensen, K.B. and C.D. Boyer. 1986. Carbohydrate composition and sensory quality of fresh and stored sweet corn. J. Amer. Soc. Hort. Sci. 111:734-738.

Fakorede, M.A.B. and S.B. Agbana. 1983. Heterotic effects and association of seedling vigor with mature plant characteristics and grain yield in some tropical maize cultivars. Maydica 28:327-338.

Gonzales, J.W., A.M. Rhodes, and D.B. Dickinson. 1974. A new inbred with high sugar content in sweet corn. HortScience 9:79-80.

Hansen, L.A. and J.R. Baggett. 1977. Reciprocal differences for plant and ear characteristics in sweet corn. HortScience 12:60-62.

Juvik, J.A., G.G. Yousef, T. Han, Y. Tadmor, F. Azanza, W.F. Tracy, A. Barzur, and T.R. Rocheford. 2003. QTL influencing kernel chemical composition and seedling stand establishment in sweet corn with the shrunken2 and sugary enhancerl endosperm mutations. J. Amer. Soc. Hort. Sci. 128:864-875.

Kurilich, A.C., S.-S. Wang, and J.A. Juvik. 1996. Sugary enhancer1 (sel) gene endosperm dosage and sweet corn carbohydrate content. HortScience 31:625 (abstr.).

Mann, C.E. and W.G. Pollmer. 1981. Relationships between maize inbred lines and the reciprocal-cross differences of their hybrids. Maydica 26:253-261.

Mann, C.E., W.G. Pollmer, and D. Klein. 1981. Magnitude and stability over environments of reciprocal-cross differences in maize hybrids and their implications on maize breeding. Maydica 26:239-252.
Marshall, S.W. and W.F. Tracy. 2003. Sweet corn, p. 537-569. In: P.J. White and L.A. Johnson (eds.). Corn: Chemistry and technology. 2nd ed. American Assn. Cereal Chemists, St. Paul, MN.

Melchinger, A.E., H.H. Geiger, and F.W. Schnell. 1985. Reciprocal differences in single-cross hybrids and their $F_{2}$ and backcross progenies in maize. Maydica 30:395-405.

Ordas, B., P. Revilla, A. Ordas, and R.A. Malvar. 2008. Hybrids sugary $\times$ sugary enhancer of sweet corn: A valuable option for cool environments. Scientia Hort. 118:111-114.

Proksch, R.K. and J.A. Juvik. 1988. Identification of sweet corn heterozygous for the se gene. HortScience 23:768 (abstr.).

Revilla, P., A. Butron, R.A. Malvar, and A. Ordas. 1999. Relationships among kernel weight, early vigor, and growth in maize. Crop Sci. 39:654-658.

Rhodes, A.M., E.E. Carey, and D.B. Dickinson. 1982. Illinois sweet corn inbreds with the suse genotype. HortScience 17:411412.

Schultz, J.A. and J.A. Juvik. 2004. Current models for starch synthesis and the sugary enhancerl (se1) mutation in Zea mays. Plant Physiol. Biochem. 42:457-464.

Tracy, W.F. 1990. Potential of field corn germplasm for the improvement of sweet corn. Crop Sci. 30:1041-1045.

Tracy, W.F. 2001. Sweet corn, p. 155-198. In: A.R. Hallauer (ed.). Specialty corns. 2nd ed. CRC Press, Boca Raton, FL. 